\title{
Consumer Behaviour and Brand Preference of Titan Watches - An empirical study with reference to Haveri District, Karnataka.
}

\author{
Anita N. Halamata \\ Teaching Assistant, Karnatak University P.G. Centre Haveri.
}

\begin{abstract}
Today human begins work with the time. The various activities to be performed on generally prescribed on the basis of time factor. Thus time is consider to be a fresher factor in every walk of life. Now-adays we find no person without a wrist watch and a home without a clock. Thus the watches have become almost a necessity for human begins, to whichever economic class they belong. This paper contets the consumer behaviour and brand preference while selecting the watches special reference to Titan Watches.

1. Introduction

2. Objectives of the study

3. Scope of the study

4. Research Methodology

5. Consumer Survey

Limitation

Survey analysis

Introduction

Demographic analysis

Respondents regarding sales services of the company

Major survey findings

Suggestions and Conclusions

- References
\end{abstract}

\section{Introduction:}

Today human begins work with the time. The various activities to be performed on generally prescribed on the basis of time factor. Thus time is consider to be a fresher factor in every walk of life. Now-adays we find no person without a wrist watch and a home without a clock. Thus the watches have become almost a necessity for human begins, to whichever economic class they belong.

In the $18^{\text {th }}$ and $19^{\text {th }}$ century watch industry has flourished in western world only, specifically Switzerland but the second half of the $20^{\text {th }}$ century has seen India emerging an important manufacturer of watches. Titan Industries a TATA group company as created history in the Indian watch industry by manufacturing and marketing different brands of watches not only in Indian market but also in the international market. This project work titled "MARKETING OF TITAN WATCHES" is a effort to study the market response to Titan brand of watches.

\section{Objectives Of The Study:}

The following are the objectives of the study towards "Marketing of Titan Watches" in Haveri City.To study consumer attitude towards "Titan range of watches".

1. To know the market share of Titan watches.

2. To know the extend of satisfaction among Titan watch users.

3. To find the extent of brand loyalty among consumers.

4. To study the factor affecting the buyers behavior.

5. To study consumer attitude towards price policies of titan watches study the consumer attitude towards company's promotional activities.

6. To study buyer reaction to after sales service.

7. To study the marketing strategy adopted in the dealers.

8. To analyze statistically responded opinion.

9. To determine consumer demographics. 


\section{Scope Of The Study:}

1. Study covers the awareness of the consumer towards Titan watches.

2. Study covers the market share of Titan watches.

3. Study covers the reasons of buying the Titan watches.

4. Study covers the consumer attitude towards the price of the Titan watches.

5. Study covers the various marketing channels of Titan watches.

6. Study covers the history of Titan watches industries.

7. Study covers the various problems faced by the company and the dealer.

8. Study is restricted to Haveri City only.

\section{Research Methodology:}

In the study both primary and secondary data has been used for the purpose of collecting data.

The primary data have been collected through the consumer survey and discussions were carried out with the consumer personally.

The secondary data has been collected from various published literature (like text books, magazines, news papers) and internet. The information regarding the organization has been collected from report and record provided by the dealers of Titan watches.

\section{Consumer survey:}

In order to collect the primary data the consumer's survey was undertaken. The sample consumers were selected on stratified random sampling method. A structured question was used to collect information from the sample consumer contacted. Even personal interviews were held with the respondents to gather unbiased information. Observation method also made used to understand the real feelings of the respondents so that study become more realistic in nature.

\section{Limitations:}

1. The study has been restricted to the users of Titan watches only.

2. The data and opinion collected are assumed to be objective.

3. The survey is restricted to 100 respondents.

4. Lack of consumer awareness about different watches.

5. Time constraint.

6. The sample size is supposed to representative of the views of the consumers.

7. The study has been restricted to Haveri city only.

\section{Introduction:}

\section{Survey Analysis}

Consumer survey is necessary in any form of marketing research because consumer is the 'king' in the market and his behavior changes day by day. Selection of products by the consumer reflects the faith in the products. The buyer's behavior changes according to their age, income, sex and other factors. Buyer's purchasing always depends on the quality and price. The study of consumer satisfaction is necessary to know the opinion of different consumers to implement the most effective marketing policy of the firm.

To conduct the consumer survey, questionnaire method was used. Questionnaire is the most common research instrument. A questionnaire is a set of questions with or without space for recording answer. The question can secure relevant facts or opinions from informed and interested respondents included in the sample survey.

In the following subsequent section, the data obtained from the respondent are analyzed statistically. A convenient sampling technique was made use for this survey and the number of respondents chosen was 100 .

\section{Demographic Analysis:}

The demographic factors pertaining to consumers are mainly age, education, occupation and income.

Table-1: Showing Gender Wise Classification Of Respondents

\begin{tabular}{|l|l|l|}
\hline Sex & No. of respondents & Percentage \\
\hline Male & 80 & 80 \\
\hline Female & 20 & 20 \\
\hline TOTAL & $\mathbf{1 0 0}$ & $\mathbf{1 0 0}$ \\
\hline
\end{tabular}




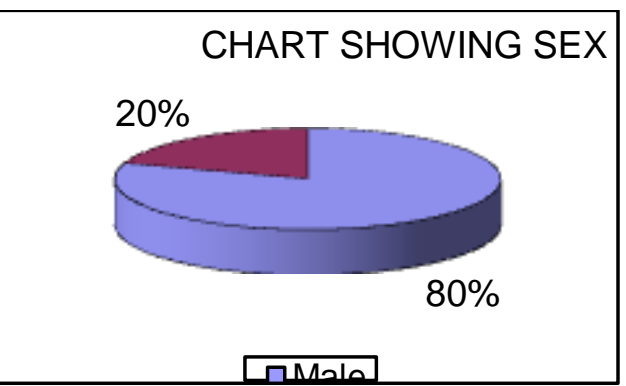

As per the table, of the respondents $80 \%$ are male and $20 \%$ are female.

Table - 2: Showing Classifiction Of Respondents On The Basis Of Age Group

\begin{tabular}{|l|l|l|}
\hline Age group (in years) & No. of respondents & Percentage \\
\hline $10-20$ & 20 & 20 \\
\hline $20-30$ & 60 & 60 \\
\hline $30-40$ & 10 & 10 \\
\hline Above 40 & 10 & 10 \\
\hline Total & $\mathbf{1 0 0}$ & $\mathbf{1 0 0}$ \\
\hline
\end{tabular}

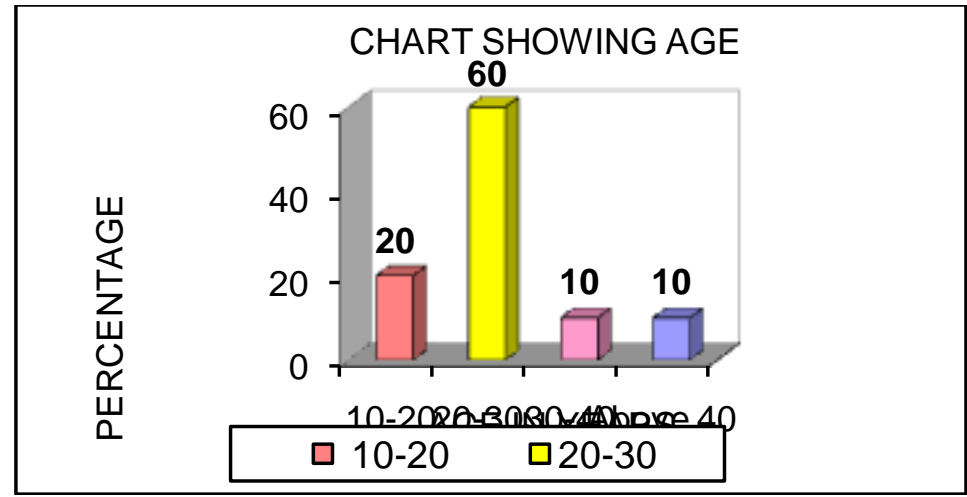

The above table indicates that majority of the respondents (60\%) belongs to the age group of 20 to 30 years, $20 \%$ belong to age group of 10 to 20 years and $10 \%$ each belongs to the age groups of 30 to 40 years and above 40 years.

Table-3: Showing Classification Of Respondents Based On Occupation

\begin{tabular}{|l|l|l|}
\hline Occupation & No.of respondents & Percentage \\
\hline Student & 60 & 60 \\
\hline Businessmen / Professional & 18 & 18 \\
\hline Government employee & 8 & 8 \\
\hline Others & 14 & 14 \\
\hline Total & $\mathbf{1 0 0}$ & $\mathbf{1 0 0}$ \\
\hline \multicolumn{3}{|c|}{ CHART SHOWING OCCUPATION } \\
\hline
\end{tabular}


The above table reveals the occupation of the respondents. Out of the total respondent $60 \%$ are student, $18 \%$ are businessmen/ professionals, $8 \%$ are government employees and remaining 14\% are other (like housewives, retired people etc.)

Table-4: Classification Of Respondents On The Basis Of Monhtly Income Of Family

8.

\begin{tabular}{|l|l|l|}
\hline Monthly income (in Rs.) & No.of respondents & Percentage \\
\hline Below 5000 & 40 & 40 \\
\hline $5000-10000$ & 14 & 14 \\
\hline $10000-15000$ & 36 & 36 \\
\hline Above 15000 & 10 & 10 \\
\hline Total & $\mathbf{1 0 0}$ & $\mathbf{1 0 0}$ \\
\hline
\end{tabular}

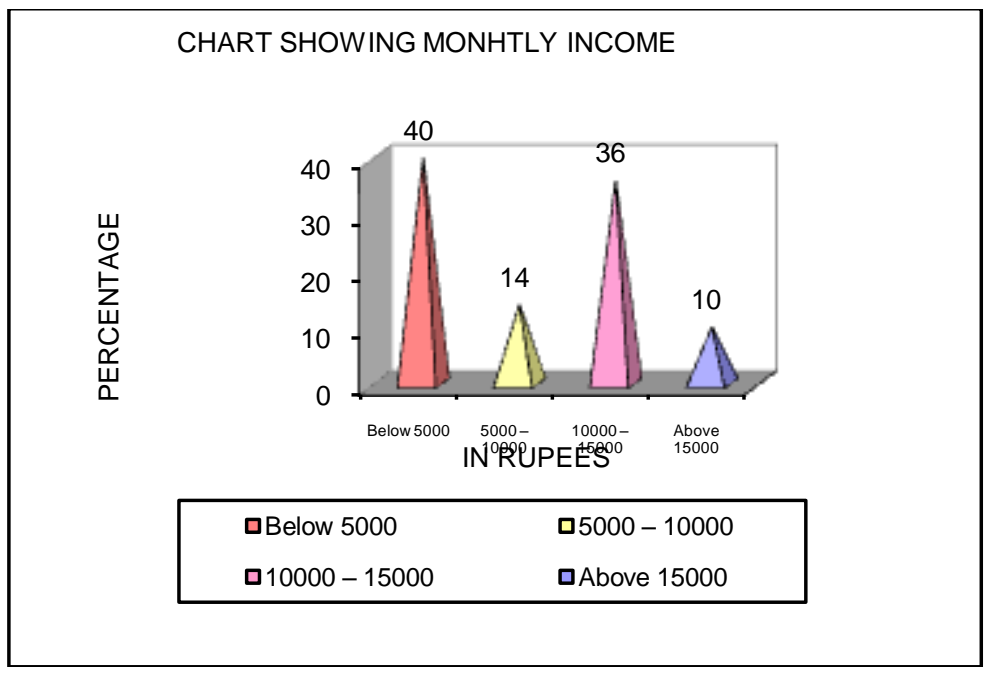

This table classifies the respondents based on monthly income. Of the respondents $40 \%$ belong to the income group of below Rs. 5000, 36\% to the income group of Rs. 10000 to Rs. $15000,14 \%$ to the income group of Rs.5000 to Rs. 10000 and $10 \%$ to above Rs. 15000 group.

Table - 5: Classification Of Respondents Based On Qualification

\begin{tabular}{|l|l|l|}
\hline Qualification & No. of respondents & Percentage \\
\hline S.S.L.C. & 10 & 10 \\
\hline Graduate & 60 & 60 \\
\hline Post-graduate & 4 & 4 \\
\hline Others & 26 & 26 \\
\hline Total & $\mathbf{1 0 0}$ & $\mathbf{1 0 0}$ \\
\hline
\end{tabular}

From the above table it can be seen that of the respondents, $10 \%$ have studied up to S.S.L.C., $60 \%$ are graduates, $4 \%$ are post graduate and remaining $26 \%$ are others (like P.U.C., Engineering).

Table - 6: Showing Classification Of Respondnets On The Brand Of Watches Owned

\begin{tabular}{|l|l|l|}
\hline Brand of watch & No. of respondents & Percentage \\
\hline Titan & 40 & 40 \\
\hline Timex & 24 & 24 \\
\hline Sonata & 16 & 16 \\
\hline Fastrack & 6 & 6 \\
\hline Others & 14 & 14 \\
\hline Total & $\mathbf{1 0 0}$ & $\mathbf{1 0 0}$ \\
\hline
\end{tabular}




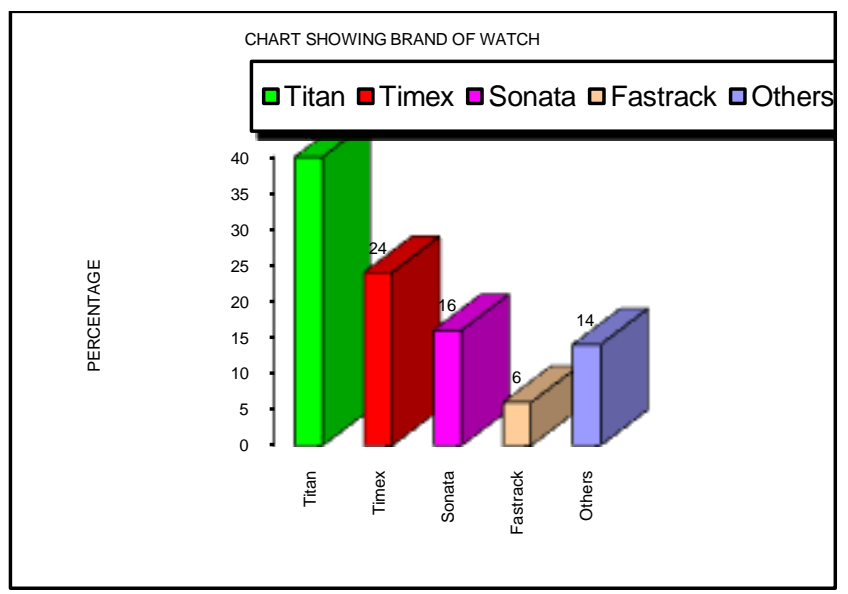

The table shows that $40 \%$ of respondents owned Titan brand watches, $24 \%$ Timex brand of watches, $16 \%$ Sonata brand of watches, $6 \%$ Fast track brand of watches and remaining $14 \%$ owned other brand like HMT, Citizen, and Maxima etc.

Table - 7: Classification Of Respondnets Based On The Source Of Information About Titan Watches

\begin{tabular}{|l|l|l|}
\hline Source of information & No. of respondents & Percentage \\
\hline Advertisement & 14 & 35 \\
\hline Relatives & 14 & 35 \\
\hline Friends & 12 & 30 \\
\hline Total & $\mathbf{4 0}$ & $\mathbf{4 0}$ \\
\hline
\end{tabular}

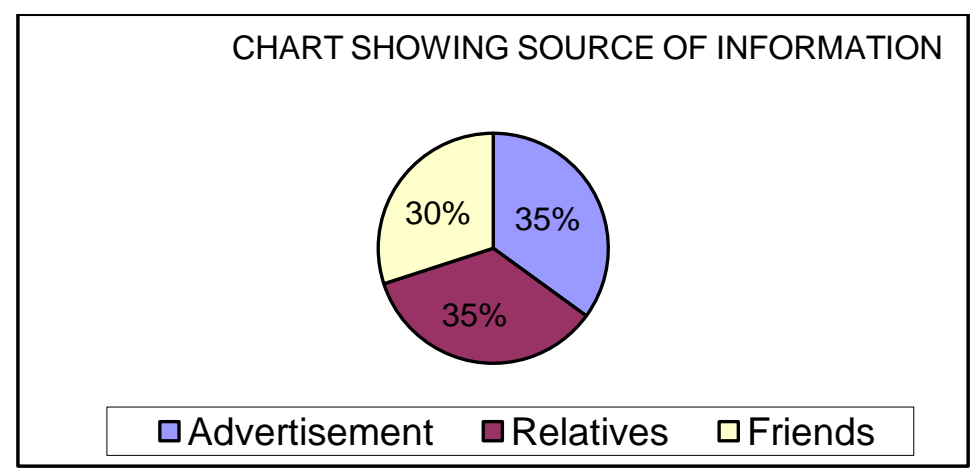

The above table indicates the sources of information about Titan watches. Of the 40 respondents, 35\% each came to know about the Titan brand of watches through advertisement and relatives and $30 \%$ through their friends.

Table8-: Classification Of Respondents On The Basis Of Plan To Change Watch

\begin{tabular}{|l|l|l|}
\hline Period (in years) & No.of respondents & Percentage \\
\hline Less than year & 20 & 20 \\
\hline 1 to 3 & 34 & 34 \\
\hline 3 to 5 & 28 & 28 \\
\hline Above 5 years & 18 & 18 \\
\hline Total & $\mathbf{1 0 0}$ & $\mathbf{1 0 0}$ \\
\hline
\end{tabular}

9. 


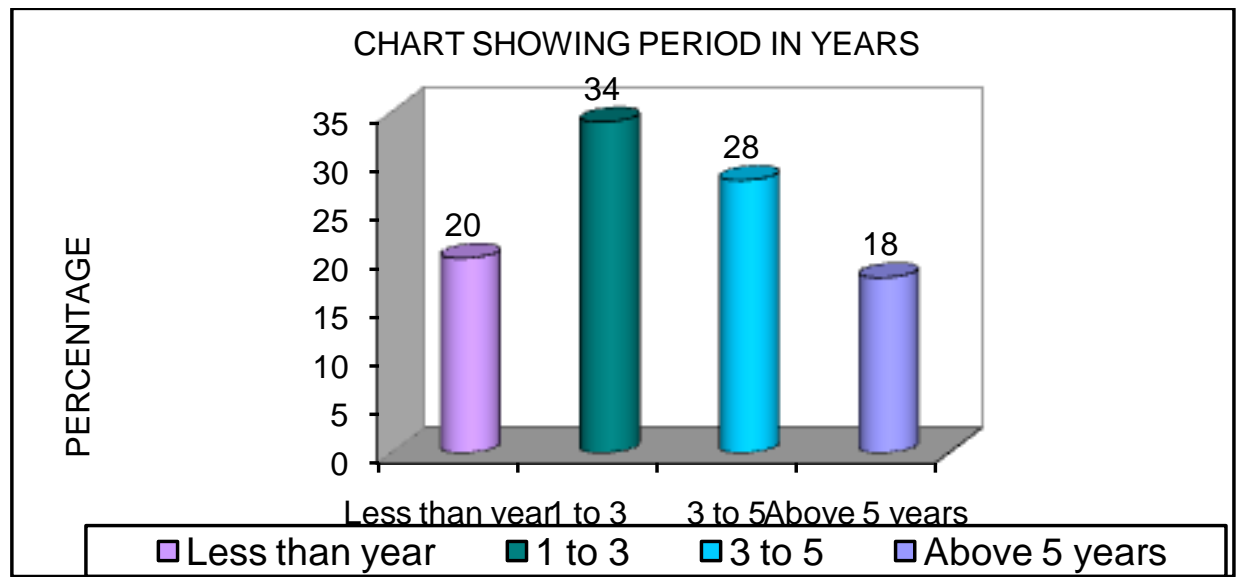

As per the above table, $34 \%$ of the respondents wants to change the watch in a period of 3 years, $28 \%$ in 3 to 5 years, $20 \%$ in less than a year and $18 \%$ after 5 years.

Table-9: Showing The Table Of Respondent On The Basis Of Opinion Abou The Performance Of Titan Watch

\begin{tabular}{|l|l|l|}
\hline Opinion & No. of respondents & Percentage \\
\hline Excellent & 14 & 35 \\
\hline Good & 16 & 40 \\
\hline Satisfied & 6 & 15 \\
\hline Unsatisfied & 4 & 10 \\
\hline Total & $\mathbf{4 0}$ & $\mathbf{1 0 0}$ \\
\hline
\end{tabular}

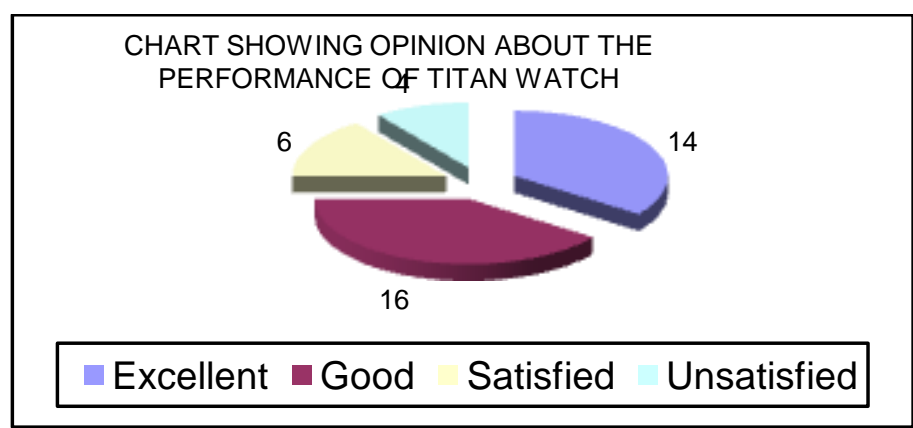

The above table indicates the opinion of the respondents regarding the performance of titan watches. Of the 40 respondents, $35 \%$ consider the performance as excellent, $40 \%$ as good, $15 \%$ as satisfied and remaining $10 \%$ are not satisfied with the performance of titan watches.

\section{Respondents Regarding After Sales Service Of The Company}

Of the respondents $90 \%$ of the satisfied of the after sales service of the dealer and remaining $10 \%$ feel dis-satisfied with the after sales service of the dealer.

\section{Major Survey Findings:}

1. Majority of the respondents are male.

2. Most of the respondents belong to the age group of 20-30 years.

3. Most of the respondent belongs to the occupation of student.

4. Majority of the respondent's monthly income were below Rs.5000.

5. Most of the respondents belong to the qualification of graduates.

6. The majority of respondents owned titan brand watches.

7. The majority of respondents are come to know about the titan brand watches through advertisement and relatives.

8. Most of the respondents belong to the plan to change watch in a period of 3 years.

9. Most of the respondents belong to the wish price range of Rs.500-1500.

10. The majority of respondents feel that the price of the titan watches as high. 
11. Most of the respondents belongs to the mode of owning watch are bought.

12. The majority of respondents are occasion of watch gift from birthday.

13. The majority of respondents are occasion of watch bought from birthday.

14. Most of respondents belong to the opinion about the performance of titan watch as good.

15. Majority of respondents feel satisfied about the after sales service.

\section{Suggestions:}

\section{Suggestions And Conclusion}

The survey of consumers has revealed the like and dislikes and taste regarding wrist watches and satisfaction level in relation to Titan industries Ltd. The consumers have forwarded the following suggestions for the consideration of the company and dealers.

1. The respondents feel that the price of Titan watches is too high. They anticipate a reduction in the price, which can be affordable to all common class of people.

2. The service for the new watches should be improved.

3. One service mechanic must be provided by the company at every showroom to ensure consumers good service and advice.

4. Some respondents feel that the price of spares of Titan watches is high and suggest for a reduction in prices.

5. Some more attractive festival offers and gifts should be given on purchases.

6. All varieties of watches should be made available in show room, which cater to the taste of different income group customers.

7. Quality of the leather straps (belt) of watches should be improved.

8. Advertisements in local media should be increased. This may cover rural areas also.

9. Guarantees should be given for costly interior parts of watch.

10. Some respondents suggested that Titan industries Ltd., should manufacture separate kids and sports watches.

11. The dealer has to improve after sales service to satisfy the customers.

\section{Conclusion:}

The Titan brand of watches coming from the Titan industries is known for quality and performance in the domestic and international markets. The consumer of Titan brand watches are highly satisfied customers having pride in owning and wearing the most sophisticated, highly reliable and superior performance watch. Titan brand watches are in great demand not only in India but also abroad. It is owing to a fact that they come from a Tata group company.

The turnover of titan brand of watches has shown uptrend from year to year. Titan watches enjoy a lion's share in the domestic watch market.

Though, there, is increasing demand for all varieties of Titan a watch, a few suggestions given by the respondents is to be considered by Titan industries. The company has to put its efforts in improving quality of its watches, introduce new varieties with changing out look to appeal and attract potential customers for its products. Again the company can also consider for a reduction in the prices which may make it market leader in the years to come.

Finally it can be said that the performance of Titan watches is not only amazing but also highly satisfactory. The company can achieve further success by improvement the suggestions of the consumers.

[1] Statical methods : S.P.Gupta

\section{Reference}

[2] Methods and Techniques : C.R.Kothari

[3] Marketing Management : Philip Kotler

[4] Websites : www.titan.com

[5] www.titanworld.com 